\title{
Hydrochemical characterization of various groundwater and seepage water resources located in the Bay of Puck, Southern Baltic Sea
}

\author{
Żaneta Kłostowska $^{1,2}$, Beata Szymczycha ${ }^{1}$, Karol Kuliński ${ }^{1}$, Monika Lengier ${ }^{1}$ and \\ Leszek Łęczyński ${ }^{2}$ \\ ${ }^{1}$ Institute of Oceanology, Polish Academy of Sciences, Sopot, Poland \\ ${ }^{2}$ University of Gdańsk, Department of Marine Geology, Gdynia, Poland
}

\section{INTRODUCTION}

Submarine groundwater discharge (SGD) has been recognized as a significant source of water and chemical substances such as trace metals, nutrients, organic and inorganic carbon to the coastal zone (Oberdorfer et al. 1990; Charette et al. 2001; Slomp et al. 2004; Burnett et al. 2006; Moore 2010). In some regions SGD has been responsible for a deterioration of the coastal environment affecting the local economy and management of the area (Valiela et al. 2002; Slomp et al. 2004; Andersen et al. 2007). Particularly sensitive to the SGD are enclosed or semi-enclosed reservoirs of a limited water exchange with the open sea (Cyberski 1993). The Bay of Puck, southern Baltic Sea, due to its morphological and hydrological features, is a good example of a basin partially separated from the open sea waters (Nowacki 1993; Nowacki 1993a). Moreover, the bay itself is divided into two parts by the Rybitwa Shallow (the average depths: $21 \mathrm{~m}$ in the outer and $3 \mathrm{~m}$ in the inner part, that additionally impedes highly the water renewal in the inner part) (Korzeniewski et al. 1994; Urbanski et al. 2007). The Bay of Puck borders with the continental land in the west and the thin Hel Peninsula in the north and north-east. Both, the continental part and the peninsula differ in terms of land use and management. Interestingly, the first studies on the SGD in the Baltic Sea region were also performed at the Hel Peninsula (Sadurski 1987). They were related to the seawater intrusion due to the intense exploitation of aquifers. As a consequence several groundwater wells were closed along the Hel Peninsula. Later a reverse phenomenon has started to be observed and scientists became interested in the identification and quantification of the groundwater seepage to the marine environment (Piekarek-Jankowska et al. 1992; Piekarek-Jankowska 1994; Piekarek-Jankowska et al. 1994). The anomalies in the chloride distribution due to the groundwater discharge were identified in the pore waters of the Bay of Puck sediments (Bolałek 1992). Recently, the fluxes of different chemical substances via SGD to the Bay of Puck have been estimated based on the experimental studies performed at the Hel Peninsula, off Hel (Szymczycha et al. 2012; Szymczycha et al. 2014; Szymczycha et al. 2016). In fact, the loads of P, Mn and DIC via SGD to the Bay of Puck reported by the authors are comparable to the loads supplied by the local rivers entering the basin. This suggests that the SGD can also be an important source of other chemical constituents and thus has a potential to shape the functioning of the unique ecosystem of the Bay of Puck (Szymczycha et al. 2012; Szymczycha et al. 2014; Szymczycha et al. 2016). Those estimations and conclusions were based on the assumption that the composition of the groundwater coming from the side of the Hel Peninsula and the continental part are similar. Our present research hypothesis assumes that the different aquifers exploitation, land use and management, diversified geological structure and differences in land-sea interactions along the Hel Peninsula and at the continental part differentiate the chemical composition of SGD coming from both these sides. The main aim of this study was to identify the provenance of the groundwater discharged to the bay and 
processes influencing its composition. This was done based on the chemical composition of SGD.

\section{METHODS}

The research was carried out in years 2016-2017. In order to identify SGD sites salinity was used as a groundwater tracer (Szymczycha et al. 2012). Three active areas of SGD off Hel Peninsula (Hel, Jurata, Chałupy), and three off continental part of the bay (Puck, Swarzewo and Osłonino) were identified based on salinity and chloride measurements (Figure 1). Water samples were collected along the salinity transition zone: groundwater from piezometers located in the coastal zone, groundwater and seepage water from the subterranean estuary (groundwater - seawater mixing zone) and seawater. From each point, $10 \mathrm{~mL}$ sample for ions content analysis $\left(\mathrm{Mg}^{2+}, \mathrm{Ca}^{2+}, \mathrm{K}^{+}, \mathrm{Na}^{+}\right)$were collected and filtered using syringe filters $(0.45 \mu \mathrm{m}$ pore size $)$ to the PTE vials, which were previously digested for $24 \mathrm{~h}$ in nitric acid. The sample for metals analysis were conserved with $3 \mathrm{M} \mathrm{HNO}_{3} .180 \mathrm{ml}$ of water were collected for $\mathrm{HCO}_{3}{ }^{-}, \mathrm{SO}_{4}{ }^{2-}$ and $\mathrm{Cl}^{-}$analysis. Samples for $\mathrm{HCO}_{3}{ }^{-}$were conserved with $\mathrm{HgCl}_{2}$. Samples for $\mathrm{SO}_{4}{ }^{2-}$ and $\mathrm{Cl}^{-}$were kept in refrigerator till the time of the analysis. The major ions $\left(\mathrm{Ca}^{2+}, \mathrm{Mg}^{2+}, \mathrm{Na}^{+}, \mathrm{K}^{+}, \mathrm{Cl}^{-}, \mathrm{SO}_{4}{ }^{2-}, \mathrm{HCO}_{3}{ }^{-}\right)$content was analyzed in 198 samples. The measurements of $\mathrm{Ca}^{2+}, \mathrm{Mg}^{2+}, \mathrm{Na}^{+}, \mathrm{K}^{+}$were conducted by means of AAS (SHIMADZU 6800). Concentrations of $\mathrm{HCO}_{3}{ }^{-}$and $\mathrm{Cl}^{-}$were determined by potentiometric titration using ion-selective electrodes (ISE) Cerko Lab System Potentiometry for precise titration. Chloride ions were titrated with silver nitrate $\left(0.1 \mathrm{M} \mathrm{AgNO}_{3}\right)$ and the bicarbonate ions were titrated with 0.1 molar hydrochloric acid $(0.1 \mathrm{M} \mathrm{HCl})$. The titration equivalent was determined by the first derivative (Dojlido 1987, Gajkowska-Stefańska et al. 2007). $\mathrm{SO}_{4}{ }^{2-}$ was quantified by the precipitation of a sparingly soluble $\mathrm{BaSO}_{4}$ in an acidic medium (Szczepaniak 2011). In addition, in the samples were measured parameters: the ORP, $\mathrm{pH}$ and oxygen content, with a multiparametric meter. Separation of individual types of water was made based on $\mathrm{Cl}^{-}$content (Bolałek 1992). The seepage samples with chloride ions content smaller than $1 \mathrm{gCl}^{-} \cdot \mathrm{dm}^{-3}$ were identified as groundwater samples.

\section{RESULTS}

The major ions ratios in all groundwater samples fluctuated in the range: from 0.11 to 0.94 for $\mathrm{Ca}^{2+} / \mathrm{Cl}^{-}$, from 0.08 to 1.23 for $\mathrm{Mg}^{2+} / \mathrm{Cl}^{-}$, from 2.23 to 93.50 for $\mathrm{Na}^{+} / \mathrm{Cl}^{-}$, from 0.03 to 0.66 for $\mathrm{K}^{+} / \mathrm{Cl}^{-}$, from 0.01 to 0.32 for $\mathrm{SO}_{4}{ }^{2-} / \mathrm{Cl}^{-}$, from 0.07 to 0.39 for $\mathrm{HCO}_{3}{ }^{-} / \mathrm{Cl}^{-}$, from 0.57 to 3.42 for $\mathrm{Mg}^{2+} / \mathrm{Ca}^{2+}$, while for seawater samples were in the range from 0.01 to 0.02 for $\mathrm{Ca}^{2+} / \mathrm{Cl}$, from 0.01 to 0.06 for $\mathrm{Mg}^{2+} / \mathrm{Cl}^{-}$, from 0.58 to 0.75 for $\mathrm{Na}^{+} / \mathrm{Cl}^{-}$, from 0.01 to 0.02 for $\mathrm{K}^{+} / \mathrm{Cl}^{-}$, from 2.98 to 4.79 for $\mathrm{Mg}^{2+} / \mathrm{Ca}^{2+}$. The ionic ratios in water samples from piezometers ranged from 0.04 to 1.97 for $\mathrm{Ca}^{2+} / \mathrm{Cl}^{-}$, from 0.01 to 0.32 for $\mathrm{Mg}^{2+} / \mathrm{Cl}^{-}$, from 1.11 to 88.68 for $\mathrm{Na}^{+} / \mathrm{Cl}^{-}$, from 0.01 to 0.44 for $\mathrm{K}^{+} / \mathrm{Cl}^{-}$, from 0.01 to 0.06 for $\mathrm{SO}_{4}{ }^{2-} / \mathrm{Cl}^{-}$, from 0.01 to 1.16 for $\mathrm{HCO}_{3}{ }^{-} / \mathrm{Cl}^{-}$and from 0.20 to 2.20 for $\mathrm{Mg}^{2+} / \mathrm{Ca}^{2+}$. Water samples collected in the groundwater wells were characterized by the range: from 0.45 to 5.67 for $\mathrm{Ca}^{2+} / \mathrm{Cl}^{-}$, from 0.09 to 0.62 for $\mathrm{Mg}^{2+} / \mathrm{Cl}^{-}$, from 0.78 to 0.85 for $\mathrm{Na}^{+} / \mathrm{Cl}^{-}$, from 0.08 to 0.34 for $\mathrm{K}^{+} / \mathrm{Cl}^{-}$, from 0.03 to 4.49 for $\mathrm{SO}_{4}{ }^{2-} / \mathrm{Cl}^{-}$, from 2.90 to 20.23 for $\mathrm{HCO}_{3}{ }^{-} / \mathrm{Cl}^{-}$and from 0.18 to 0.35 for $\mathrm{Mg}^{2+} / \mathrm{Ca}^{2+}$. The maximum ratios in groundwater samples collected in the subterranean estuary were observed in Chałupy region and equal to 0.79 for $\mathrm{Ca}^{2+} / \mathrm{Cl}^{-}, 1.23$ for $\mathrm{Mg}^{2+} / \mathrm{Cl}^{-}, 25.17$ for $\mathrm{Na}^{+} / \mathrm{Cl}^{-}$and 0.66 for $\mathrm{K}^{+} / \mathrm{Cl}^{-}$, respectively. Comparable results were detected also in Swarzewo. In case of water samples coming from piezometers, the maximum ratios were observed in $\mathrm{Hel}$ and equal to 0.72 for $\mathrm{Ca}^{2+} / \mathrm{Cl}^{-}, 0.27$ for $\mathrm{Mg}^{2+} / \mathrm{Cl}^{-}, 34.87$ for $\mathrm{Na}^{+} / \mathrm{Cl}^{-}, 0.08$ for $\mathrm{K}^{+} / \mathrm{Cl}^{-}, 0.06$ for $\mathrm{SO}_{4}{ }^{2-} / \mathrm{Cl}^{-}, 0.46$ for $\mathrm{HCO}_{3}{ }^{-} / \mathrm{Cl}^{-}$, while the lowest ratios were recorded in Jurata and equal to $0.04,0.01,0.01,0.0048$ and 0.01 , respectively. The ratios for groundwater samples collected 
in wells were highest in Swarzewo and equal to 5.67 for $\mathrm{Ca}^{2+} / \mathrm{Cl}^{-}, 0.62$ for $\mathrm{Mg}^{2+} / \mathrm{Cl}^{-}, 0.85$ for $\mathrm{Na}^{+} / \mathrm{Cl}^{-}, 0.34$ for $\mathrm{K}^{+} / \mathrm{Cl}^{-}, 4.49$ for $\mathrm{SO}_{4}{ }^{2-} / \mathrm{Cl}^{-}, 20.24$ for $\mathrm{HCO}_{3}{ }^{-} / \mathrm{Cl}^{-}$, except $\mathrm{Mg}^{2+} / \mathrm{Ca}^{2+}(0.35)$ that was identified in the Jurata.

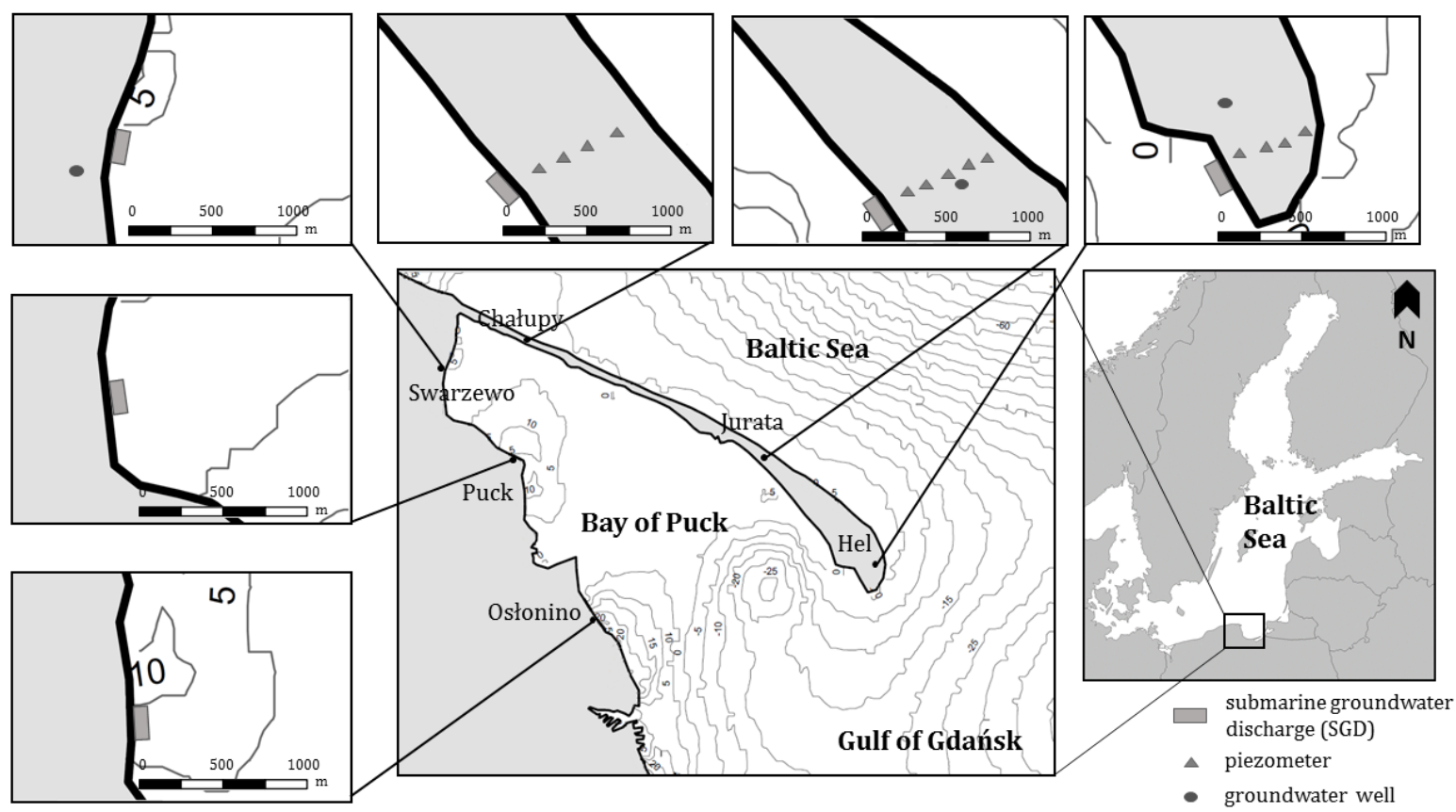

Figure 1. Map of the Bay of Puck showing the active areas of submarine groundwater discharge (SGD), locations of piezometers and groundwater well, along the Hel Peninsula (Hel, Jurata, Chałupy), and in the continental part of the bay (Puck, Swarzewo and Osłonino).

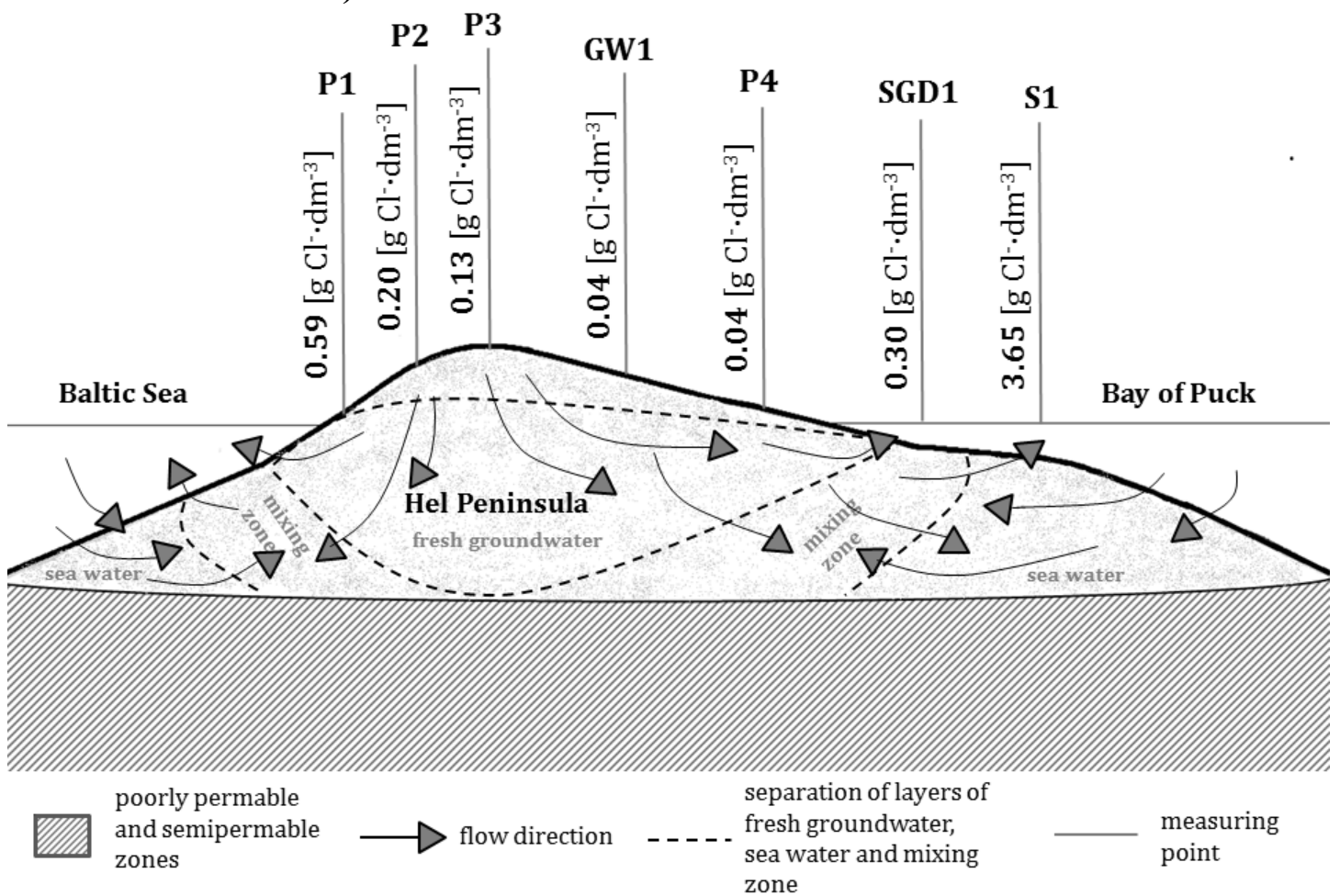

Figure 2. Schematic distribution of chloride concentration $\left[\mathrm{gCl}^{-} \cdot \mathrm{dm}^{-3}\right]$ at submarine groundwater discharge (SGD), piezometers (P), groundwater well (GW) and sea water (S) in the Hel Peninsula, of Hel. Sampling points are marked schematically. 


\section{DISCUSSION AND CONCLUSIONS}

The preliminary results indicate that SGD composition in Chałupy and Swarzewo are comparable. This suggests that groundwater discharged from both these sites located in the Inner Bay of Puck can have similar source. This hypothesis will be further verified by the analysis of the oxygen stable isotopes. For Hel and Jurata the ionic composition of the groundwater samples is mainly influenced by the land-sea interactions. Thus the increase of seawater level and atmospheric conditions such as storms will result in higher seawater intrusion (Sadurski, 1987). The vertical cross-section of groundwater composition located in Hel (Figure 2) is conditioned by the processes associated with the movement of seawater masses. This is observed at both sites of the peninsula. Osłonino and Swarzewo characterized with totally different ratios in comparison to other areas which can be explained by possible different source of groundwater relating to different land use and management. The results show that there is no clear separation between continental part and the peninsula in terms of groundwater composition. Further studies are necessary to understand the groundwater provenance and factors influencing SGD in the Bay of Puck.

\section{ACKNOWLEDGMENTS}

Acknowledgments The study reports results obtained within the framework of the following projects: UMO-2016/21/B/ST10/01213 sponsored by National Science Center and WaterPUCK financed by the National Centre for Research and Development (NCBR) within BIOSTRATEG program.

\section{REFERENCES}

Andersen S., Baron L., Gudbjerg J., Gregersen J., Chapellier D., Jakobsen R., Postma D., 2007. Discharge of nitrate-containing groundwater into a coastal marine environment. J. Hydrol., 336, 98 114

Bolałek J. 1990, Ionic macrocomponets of the interstitial waters of Puck Bay. Oceanologia, 33, 131159

Burnett W.C., Aggarwal P.K., Aureli A., Bokuniewicz H.J., Cable J.E., Charette M.A., Kontar E., Krupa S., Kulkarni K.M., Loveless A., Moore W.S., Oberdorfer J.A., Oliveira J., Ozyurt N., Povinec P., Privitera A.M.G., Rajar R., Ramessur R.T., Scholten J., Stieglitz T., Taniguchi M., Turner J.V., 2006. Quantifying submarine groundwater discharge in the coastal zone via multiple methods. Sci. Total Environ., 367, 498-543

Charette M.A., Buesseler K.O., Andrews J.E., 2001. Utility of radium isotopes for evaluating the input and transport of groundwater-derived nitrogen to a Cape Cod estuary. Limnol. Oceanogr., 46, $465-470$

Cyberski J. 1993. Hydrologia zlewiska i morfometria zatoki. Korzeniewski K., Zatoka Pucka. Gdańsk: Instytut Oceanografii Uniwersytetu Gdańskiego. 40

Dojlido J., 1987. Chemia wody, Arkady, Warszawa

Gajkowska-Stefańska L., Guberski S., Gutowski W., Mamak Z., Szperliński Z. 2007, Laboratoryjne badania wody, ścieków i osadów ściekowych, Oficyna Wydawnicza Politechniki Gdańskiej, 92-96, 113-117, 181-187

Korzeniewski K. 1994. Zatoka Pucka. Inst. Ocean. UG. 
Krall L., Trezzi G., Garcia-Orellana J., Rodellas V., Mörth C. M., Andersson, P. 2017. Submarine groundwater discharge at Forsmark, Gulf of Bothnia, provided by Ra isotopes. Mar. Chem., 196, $162-172$.

Kryza J., Kryza H. 2006. The analytic and model estimation of the direct groundwater flow to Baltic Sea on the territory of Poland. Geologos 10, 154-165.

Moore WS, 2010. The Effect of Submarine Groundwater Discharge on the Ocean. Annu. Rev. Mar. Sci., 2, 59-88.

Nowacki J.. 1993a. Morphometric characteristic of Puck Bay, [in:] Puck Bay, Eds. Korzeniewski K., Fundacja Rozwoju Uniwersytetu Gdańskiego, Gdańsk, 71-78.

Nowacki J. 1993. Thermics, salinity and density of water, [in:] Puck Bay, K.Korzeniewski (ed.), Fundacja Rozwoju Uniwersytetu Gdańskiego, Gdańsk, 79-111.

Oberdorfer JA, Valentino MA, Smith SV, 1990. Groundwater contribution to the nutrient budget of Tomas Bay, California. Biogeochemistry 10, 199-216.

Pempkowiak J., Szymczycha B., Kotwicki L. 2011. Podwodny dopływ podziemny do morza Bałtyckiego. Rocznik Ochrona Środowiska, 12, 1, 17-32.

Piekarek-Jankowska H., Bolałek J. 1992. Jon chlorkowy w wodach porowych osadów dennych Zatoki Puckiej. Wyd. UG, Gdańsk.

Piekarek-Jankowska H. 1994. Zatoka Pucka jako obszar drenażu wód podziemnych. Wyd. UG, Gdańsk.

Piekarek-Jankowska H., Matciak M., Nowacki J. 1994. Salinity variations as an effect of groundwater seepage through the seabed (Puck Bay. Poland).Oceanologia, 36,1, 33-46.

Piekarek-Jankowska H. 2007. Podmorski drenaż wód podziemnych gdańskiego system wodonośnego: Gdański system wodonośny. Edited by Kozerski B, 2010. Wydawnictwo Politechniki Gdańskiej, Gdańsk, Poland, 34-49.

Peltonen K., 2002. Direct Groundwater Inflow to the Baltic Sea. TemaNord, Nordic Councils of Ministers, Copenhagen, Holand, 79.

Sadurski A. 1987. Warunki hydrogeologiczne i hydrochemiczne Mierzei Helskiej, Geol. Q., 1987, 31 (4), 767-782.

Slomp C.P., Van Cappellen P. 2004. Nutrient inputs to the coastal ocean through submarine groundwater discharge: controls and potential impact. J. Hydrol., 295, 64-86.

Szczepaniak W. 2011. Metody instrumentalne w analizie chemicznej. Wydawnictwo Naukowe PWN, Warszawa.

Szymczycha B., Vogler S., Pempkowiak J. 2012. Nutrient fluxes via submarine groundwater discharge to the Bay of Puck, Southern Baltic, Sci. Total Environ., 438, 2012, 86-93.

Szymczycha B., Maciejewska A., Winogradow A., Pempkowiak J. 2014. Could submarine groundwater discharge be a significant carbon source to the southern Baltic Sea?, Oceanologia, 56, $327-347$. 
Szymczycha B., Kroeger K. D., Pempkowiak J. 2016. Significance of groundwater discharge along the coast of Poland as a source of dissolved metals to the southern Baltic Sea, Mar. Pollut. Bull., 109, $1,151-162$.

Urbański J., Grusza G., Chlebus N. 2007. Fizyczna typologia dna Zatoki Gdańskiej. Gdynia: Pracownia Geoinformacji Zakładu Oceanografii Fizycznej, Instytut Oceanografii UG. 8.

Uścinowicz Sz., Miotk-Szpiganowicz G. 2011. The Baltic Sea: Location, Division and Catchment Area: Geochemistry of Baltic Sea Surface and Sediments. (ed) Uścinowicz Sz, 2011. Polish Geological Institute-National Research Institute, Warsaw, Poland, 13-17.

Valiela I., Bowen J.L., Kroeger K. D. 2002. Assesment of models for estimation of land-derived nitrogen loads to shallow estuaries. Appl. Geochem., 17, 935-953.

Contact Information: Żaneta Kłostowska, Institute of Oceanology, Polish Academy of Sciences, Powstańców Warszawy 55, 81-712 Sopot, Poland Email: klost@iopan.pl 